\title{
Effect of rootstocks on growth, yield and fruit quality of red globe grape.
}

\author{
Hifny, H. A., Baghdady, G. A., Abdrabboh, G. A., Sultan, M. Z. and Shahda, M.A. \\ Department of Horticulture, Faculty of Agriculture, Al-Azhar University, Nasr city, Cairo, Egypt. \\ Corresponding author: moh_grap80@yahoo.com
}

\begin{abstract}
The current investigation was conducted during the two successive seasons of 2013 and 2014 on six years old vines grown in a sandy soil of a private orchard located at Wadi Almollak, Ismailia Governorate, Egypt. Vines of Red globe cv. were grafted on three different rootstocks namely Freedom, Richter and Salt Creek, cvs. in addition to the own-rooted vine cultivar to evaluate their effects on growth, yield and fruit quality. The results showed that rootstocks had a positive impact on growth, yield and fruit quality of Red globe grapevines. Red globe grafted on Salt creek rootstock recorded the highest values of leaf area followed by other rootstocks and those on own roots, while insignificant difference were noticed regarding leaves number. Maximum values of shoot length were obtained when Red globe was grafted on Freedom rootstock while the lowest values were recorded by Richter rootstock. Regarding chemical properties of berries, Red globe grafted on Freedom rootstock recorded the highest percentage of TSS, TSS / acid ratio and anthocyanin content. No difference between percentages of acidity in the berry juice of Red globe grafted on any rootstock was noticed. Insignificant differences were noticed regarding yield as $\mathrm{kg}$ / tree when Red globe cv. was grafted on any rootstock.
\end{abstract}

Keywords: Rootstocks, Growth, Fruit Quality, Red Globe Grape

\section{Introduction}

Grape (Vitis vinifera L.) is one of the most wildly cultivated fruit crops all over the world, covering an area of more than 10 Millions Hectare. In Egypt, it is one of the most important fruit crops of temperate zone, it is considered the second most important fruit crop after Citrus. The planted area reached 192934 fedan in 2014 producing 1596169 tons (Ministry of Agriculture statistics, 2015) The production of grapes increased as a result of introducing new varieties and rootstocks, improved culture practices, post-harvest handling as well as a new marketing. Vine rootstocks, as a link between the soil and the scion, play an important role in vine adaptation to environmental factors. Choosing the rootstock is one of the most important decisions when establishing vineyards. Rootstocks are employed in grape cultivation to overcome several biotic stresses, abiotic stresses and, to a limited extent, for controlling vegetative growth, precocity and fruit quality. Numerous studies have shown that rootstocks can affect to measure the vine growth parameters, flower development, yield and fruit quality (Bica et al., 2000; Ollat et al., 2003 and Turker and Ak, 2010). Rootstocks affect vine growth, yield and fruit quality through the interactions between the environmental factors, the physiology of scions and rootstock cultivars employed. Cluster weight, berry size and soluble solids content were also affected by rootstocks (Zhiyuan, 2003 and Gaser 2007). Grapevine rootstocks can also affect yield and fruit quality. Limited information in Egypt about the importance of using grafted vines is available. Accordingly, the main goal of this investigation was to study the effect of some grape rootstocks such as Freedom, Salt creek, and Richter in addition to those on own-roots on growth, yield and fruit quality of Red Globe grape vines.

\section{Material and Methods}

This investigation was conducted for two successive seasons (2013and 2014) in a private vineyard located at Wadi Almollak, Ismailia Governorate, Egypt, to study the effect of some rootstocks namely, Freedom, Salt creek and Richter in addition to own-rooted vines on growth, yield and fruit quality of Red Globe grapevines. These rootstocks were characterized according to (Schmid et al., 1998; Sule, 1999; Walker et al., 2002 and Ozden et al., 2010) as follows:

Freedom (1613 Couderc $x$ V. champini): moderate to high vigor, highly resistant to nematodes and phylloxera and moderate drought tolerant.

Salt creek ( $V$. champini): very high vigorous with quite resistance to nematodes, moderate resistant to phylloxera and moderate drought tolerant.

Richter 110 ( $V$. berlandieri $x V$. rupestris) low vigorous across a wide range of soils and site conditions, good drought tolerant, good for phylloxera resistance, but is susceptible to root-knot and dagger nematodes and low to medium yields. Vines were 5 years old and grown in a sandy soil and drip irrigation. Sixty vines were selected and arranged into four 
similar groups (Blocks), each of five vines (replicate). The experimental vines were arranged in complete randomized block design. The Gable system was used as a trellising system. The vines were pruned during the third week of January with bud load of (75 buds/vine).

\subsection{Effect of rootstocks on vegetative growth of Red globe grapevines.}

At growth cessation, the following morphological and chemical determinations were carried out on 5 shoots/vines. Average shoot length (cm), was determined biweekly. Average number of leaves/shoot, was recorded at full bloom stage. Average leaf area $\left(\mathrm{cm}^{2}\right)$ was calculated using the equation of Montero $\boldsymbol{e t}$ al., (2000) as follow: LW (0.587) whereas $\mathrm{L}=$ leaf length $\mathrm{W}=$ leaf width.

\subsection{Yield, cluster and berry physical characteristics.}

Yield/vine (kg) was determined as number of clusters/vine, then nine cluster/vine were employed to determine the average cluster weight $(\mathrm{g})$ cluster length and width $(\mathrm{cm})$, Average 100 berries weight $(\mathrm{g})$, average 100 berries size $(\mathrm{cm} 3)$, were determined.

\subsection{Chemical characteristics of berries:}

Nine clusters/vine were harvested at 16-17 \% TSS according to Tourky et al., (1995). Total soluble solids in berry juice (T.S.S. \%) were determined using a digital refractometer and total titratable acidity expressed as tartaric acid (\%) according to (A.O.A.C.,
1985). TSS /acid ratio and total anthocyanin of the berry skin $(\mathrm{mg} / 100 \mathrm{~g}$ fresh weight) were determined according to Husia et al., (1965).

Statistical analysis:

A completely randomized block design was followed whereas one factor vines were compared with rootstocks. The results were statistically analyzed using F-value test, and the means were compared by the L.S.D at the level of $5 \%$ probability according to Snedecor and Cochran (1980).

\section{Results and Discussion}

\subsection{Effect of rootstocks on vegetative growth: 3.1.1. Shoot length.}

Data in Table (1) and Fig (1) showed that shoot length increased gradually through the considered sampling dates. There were significant differences in shoot length between the three rootstocks beside those of own rooted plants. It was clear that Freedom rootstock was the superior when compared with other two rootstocks, whereas it possessed the highest values followed descendly by Salt creek and Richter which gained the lowest values.

The results in this respect are in line with those of Fardossi et al. (1995) who found that shoot growth expressed as (stem diameter) of Gruner Veltliner grape was slower when grafted on 5C and Fercal rootstocks, but more rapid on 1103P, 725P and 125AA ones. In addition, Colldecarrera et al. (1997) reported that rootstocks $110 \mathrm{R}, \mathrm{SO} 4$ and 140 Ruggeri had the most vigorous as well as the most productive scions.

Table 1. Effect of some grape rootstocks on shoot length of Red globe variety in 2013 and 2014 seasons.

\begin{tabular}{|c|c|c|c|c|c|c|}
\hline $\begin{array}{l}\text { Date } \\
\quad \text { Rootstocks }\end{array}$ & $21^{\text {st } m a r c h}$ & $28^{\text {th }}$ March & $4^{\text {th }}$ April & $18^{\text {th }}$ April & $1^{\text {st }}$ May & $8^{\text {th }}$ May \\
\hline \multicolumn{7}{|c|}{ Shoot length $(\mathrm{cm})$} \\
\hline \multicolumn{7}{|c|}{2013 season } \\
\hline Own root & $40.00 \quad \mathrm{a}$ & $57.00 \mathrm{a}$ & $82.67 \quad \mathrm{a}$ & $133.00 \mathrm{a}$ & $160.33 \mathrm{~b}$ & $196.67 \mathrm{~b}$ \\
\hline Freedom & $41.00 \mathrm{a}$ & $53.00 \mathrm{a}$ & $77.00 \mathrm{a}$ & $129.67 \mathrm{a}$ & $166.67 \mathrm{a}$ & $206.9 \quad \mathrm{a}$ \\
\hline Richter & $33.67 \mathrm{~b}$ & $51.00 \mathrm{a}$ & $70.67 \quad b$ & $101.00 \mathrm{~b}$ & $131.33 \mathrm{~d}$ & $163.6 \mathrm{~d}$ \\
\hline Salt creek & $18.33 \mathrm{c}$ & $36.00 \mathrm{~b}$ & $65.00 \mathrm{c}$ & $98.33 \mathrm{~b}$ & $141.33 \mathrm{c}$ & $173.75 \mathrm{c}$ \\
\hline \multicolumn{7}{|c|}{2014 season } \\
\hline Own root & $33.43 \mathrm{a}$ & $50.43 \mathrm{a}$ & $74.37 \mathrm{ab}$ & $132.00 \mathrm{~b}$ & $162.82 \mathrm{~b}$ & $207.23 \mathrm{~b}$ \\
\hline Freedom & $28.46 \mathrm{a}$ & $38.80 \mathrm{~b}$ & $77.97 \mathrm{a}$ & $143.23 \mathrm{a}$ & $178.47 \mathrm{a}$ & $229.93 \mathrm{a}$ \\
\hline Richter & $32.23 \mathrm{a}$ & $50.90 \mathrm{a}$ & $75.27 \mathrm{ab}$ & $136.63 \mathrm{~b}$ & $163.90 \mathrm{~b}$ & $191.30 \mathrm{c}$ \\
\hline Salt creek & $24.57 \mathrm{a}$ & $42.23 \mathrm{~b}$ & $71.97 \mathrm{~b}$ & $123.17 \mathrm{c}$ & $150.58 \mathrm{c}$ & $204.20 \mathrm{~b}$ \\
\hline
\end{tabular}




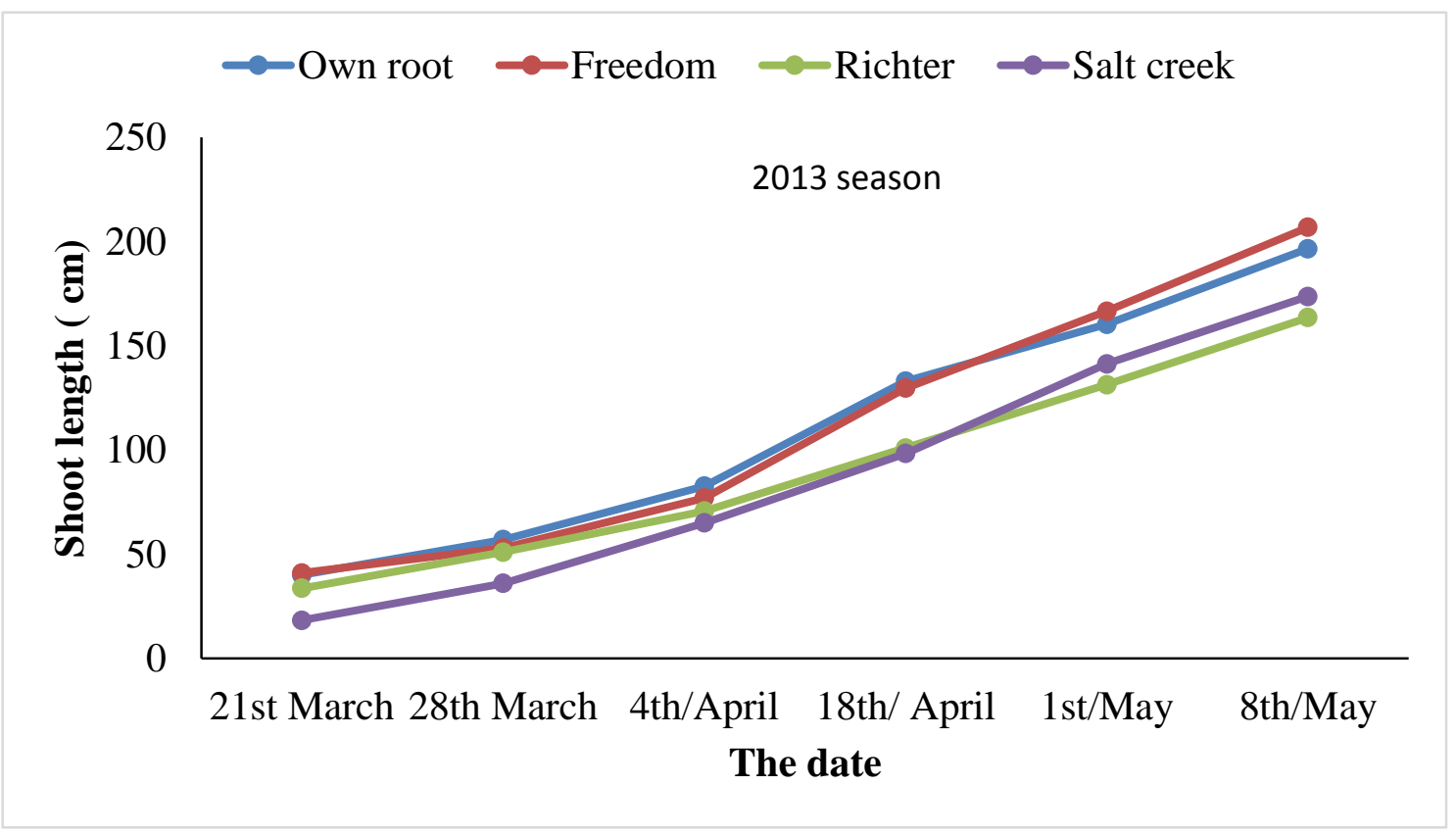

Fig. (1): Effect of some grape rootstocks on shoot length of Red globe variety in 2013 season.

\subsubsection{Number of Leaves and average leaf area}

Data in Table (2) indicated that there was an insignificant difference between the rootstocks regarding number of leaves /shoot while, significant difference was noticed regarding average leaf area. It was found that Salt creek rootstock was superior rather than the other two rootstocks Freedom and Richter as it recorded the highest value while the own-rooted recorded the lowest ones.

The results are in agreement with those of ELMorsi et al., (2006) who found that leaf surface area per vine was bigger than those of ungrafted ones. They reported that grafting Superior scion on Freedom rootstock significantly increased the leaf area parameter in the present study. The ameliorative effect of the grafting on leaf area could be attributed to the high efficiency of the root system of Salt Creek rootstock in absorbing and transporting the water and minerals via the grafted union to the shoots of Superior scion and also may be to the favorable reciprocal relationship between scion and stock.

Table 2. Effect of some grape rootstocks on number leaves of /shoot and leaf area in Red globe grapevines in 2013 and 2014 seasons.

\begin{tabular}{lllll}
\hline & Character & Number of leaves/shoot & Leaf area $\left(\mathrm{cm}^{2}\right)$ \\
\hline Rootstocks & \multicolumn{2}{c}{2013 season } & \\
\hline Own root & 19.33 & $\mathrm{a}$ & 151.20 & $\mathrm{~b}$ \\
\hline Freedom & 19.00 & $\mathrm{a}$ & 152.78 & $\mathrm{~b}$ \\
\hline Richter & 19.33 & $\mathrm{a}$ & 156.56 & $\mathrm{~b}$ \\
\hline Salt creek & 17.67 & $\mathrm{a}$ & 167.24 & $\mathrm{a}$ \\
\hline & 2014 season & \\
\hline Own root & 22.00 & $\mathrm{a}$ & 156.54 & $\mathrm{~b}$ \\
\hline Freedom & 21.33 & $\mathrm{a}$ & 160.59 & $\mathrm{~b}$ \\
\hline Richter & 20.00 & $\mathrm{a}$ & 159.79 & $\mathrm{~b}$ \\
\hline Salt creek & 20.33 & $\mathrm{a}$ & 177.30 & $\mathrm{a}$ \\
\hline
\end{tabular}

3.2. Effect of rootstocks on Yield of Red globe grapevines.

Data in Table (3) showed that, Yield of Red globe cv. was insignificantly increased when grafted on
Freedom and Salt creek rootstocks compared with Richter rootstock and own rooted vines.

The results are in partial agreement with RizkAlla et al., (2011) who observed that Red Globe 
grafted onto Dog Ridge, Salt creek and Freedom possessed the highest yield values, followed descendly by those grafted onto Harmony and Paulsen 1103 rootstocks which produced an intermediate yield, while those of own-rooted vines gained the lowest values.

El-Gendy (2013) found that yield of Flame Seedless cv. grafted on Freedom or Salt Creek increased yield than those on Flame Seedless and own roots. Salt Creek rootstocks found to be superior rather than other rootstocks such as yield of Flame scion.

3.3. Berry characteristics of Red globe in relation to rootstocks:

\subsubsection{Physical characteristics}

Data in Table (3) revealed that, Salt creek and Freedom rootstocks increased both berry weight and size parameters of Red globe expressed as (100 berries) compared with Richter rootstock and those on own rooted trees.

The obtained results are similar to those mentioned by EL-Morsi et al.,(2006), Gaser,(2007) and Abo EL-Wafa (2009) who reported that berry weight parameters; size, length and diameter of superior cv. grafted on Paulsen and Teleki rootstocks increased when compared with So4 rootstock and those on own rooted.

Table 3. Effect of some rootstocks on yield, some physical and of Red globe grapes in seasons 2013 and 2014.

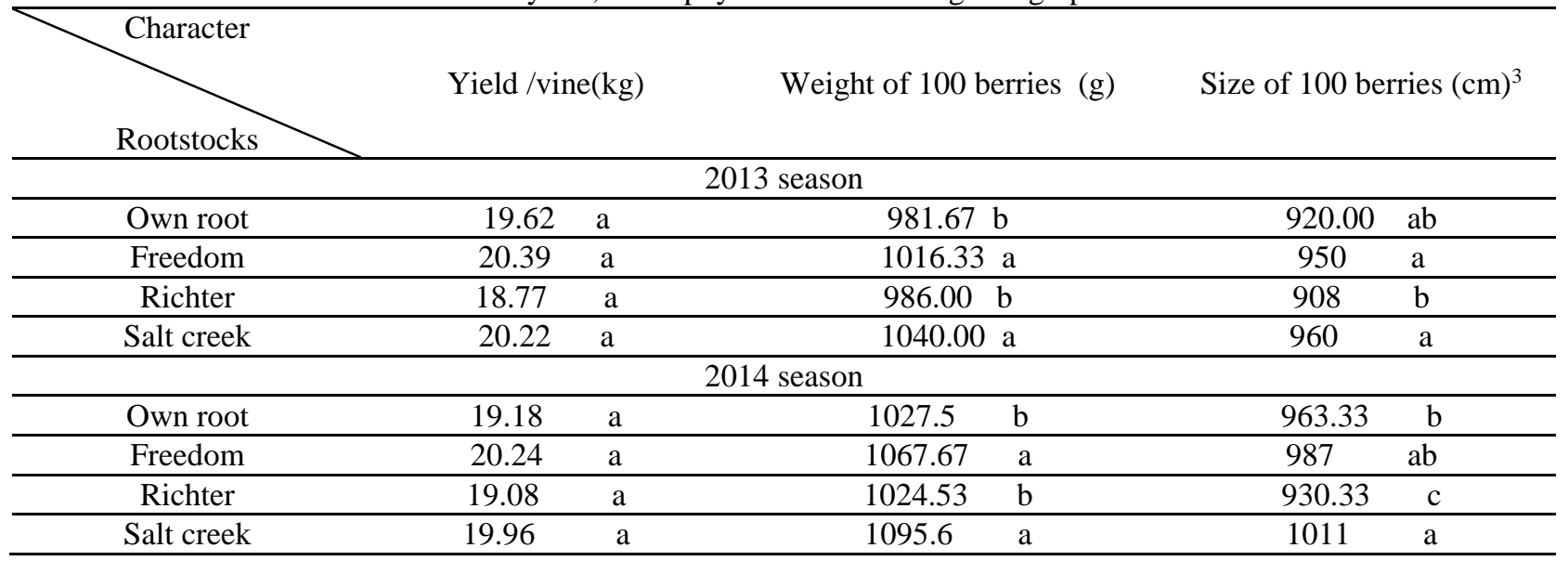

\subsubsection{Chemical characteristics.}

Data in Table (4) showed also that there is a significant difference between the rootstocks regarding TSS. It was found that Red globe grafted on Freedom rootstock possessed the highest values of TSS followed descendly by Richter rootstock and Salt creek rootstock compared with those on own-roots which recorded the lowest values. On other hand, differences between rootstocks regarding total acidity and TSS/Acid ratio were insignificant.

Table 4. Effect of rootstocks on chemical characteristics of Red globe berry in 2013 and 2014 seasons.

\begin{tabular}{|c|c|c|c|c|}
\hline$\underbrace{\text { Character }}_{\text {Rootstocks }}$ & T.S.S (\%) & Acidity $\%$ & TSS/acid ratio & $\begin{array}{c}\text { Anthocyanin } \\
\text { (mg /100g FW.) }\end{array}$ \\
\hline \multicolumn{5}{|c|}{2013 season } \\
\hline Own root & $15.50 \mathrm{~b}$ & $1 \mathrm{a}$ & $15.49 \mathrm{a}$ & $80.66 \mathrm{~b}$ \\
\hline Freedom & $16.60 \mathrm{a}$ & $.090 \mathrm{a}$ & $18.44 \mathrm{a}$ & $108.33 \mathrm{a}$ \\
\hline Richter & $16.00 \mathrm{ab}$ & $0.90 \mathrm{a}$ & $18.27 \mathrm{a}$ & $105.00 \mathrm{a}$ \\
\hline Salt creek & $15.36 \mathrm{~b}$ & $0.90 \mathrm{a}$ & $18.13 \mathrm{a}$ & $86.33 \mathrm{~b}$ \\
\hline \multicolumn{5}{|c|}{2014 season } \\
\hline Own root & $14.8 \mathrm{~b}$ & $0.85 \mathrm{a}$ & $20.15 \mathrm{a}$ & $85.00 \mathrm{~b}$ \\
\hline Freedom & $16.06 \mathrm{a}$ & $0.85 \mathrm{a}$ & $19.88 \mathrm{a}$ & $112.00 \mathrm{a}$ \\
\hline Richter & $15.5 \mathrm{ab}$ & $0.82 \mathrm{a}$ & $16.73 \mathrm{a}$ & $110.89 \mathrm{a}$ \\
\hline Salt creek & $15.03 \mathrm{~b}$ & $0.70 \mathrm{a}$ & $18.79 \mathrm{a}$ & $90.00 \mathrm{~b}$ \\
\hline
\end{tabular}


Concerning the effect of some rootstocks on anthocyanin content of berry skin, it is noticed that Freedom and Richter rootstocks showed significantly the highest values compared with Salt creek rootstock and own rooted vines (Red globe).

Our results are in agreement with Rizk-Alla et $\boldsymbol{a l}$., (2011) since they found that all berry chemical parameters, including total soluble solids, titratable acidity, TSS/acid ratio as well as anthocyanin content were significantly affected by rootstocks. They also reported that Red globe grafted onto Freedom, Harmony and Paulsen 1103 rootstocks had the highest values. The highest values of TSS, TSS/acid ratio and anthocyanin content and the lowest percentages of acidity in the berry juice, followed descendly by the own-rooted vines which recorded intermediate values compared with those of grafted onto Dog Ridge and Salt creek.

\section{References}

Abo EL-Wafa,T.S. (2009). Bud behavior, growth, yield and fruit quality of superior grape as affected by different grape rootstocks .Ph.D Thesis Fac. Of Agric., Mansoura Univ.

Association of Official Agricultural Chemists (A.O.A.C.) (1985): Official Methods of Analysis Published by AOAC, Benjamin Franklin Station, Washington DC, USA.

Bica, D.; Gay, G.; Morando, A.; Soave, E. and Bravdo, B.A. (2000). Effect of rootstock and Vitis vinifera genotype on photosynthetic parameters. Acta Hort., 526: 373-379.

Colldecarrera, M.; Gispert, M.A. and Recio, J.P. (1997). The nutritional status of Chardonnay and Tempranillo in the Alt Emporda area: Effect of rootstock. Acta Hort. 448:99-105.

Ezzahouani, A. and Larry, L.E. (1997). Effect of rootstock on grapevine water status, productivity and grape quality of cultivar 'Italia'. Bulletin de l'OI V 70:703-713.

El-Gendy, R.S. (2013). Evaluation of Flame Seedless Grapevines Grafted on Some Rootstocks. Journal of Horticultural Science \& Ornamental Plants, 5(1), 0111.

EL-Morsi, F.M.; EL Gendy, R.S.S and Merrat, A.K.( 2006)Effects of two grape rootstocks on growth, yield and cluster quality of superior seedless scion cultivar under conditions of the open field and overhead plastic covering. Egypt.J of Applied Sci., 21(108)

Fardossi, A.; Brandes,W. and Mayer, C. (1995). Influence of different rootstock cultivars on growth, leaf nutrient content and must quality of cultivar Gruner Veltliner. Mitteilungen Klosterneuburg, Rebe und Wein, Obstbau und Fruchteverwertung 45:3-15.
Gaser, A.S.A. (2007). Impact of some rootstocks on performance of superior grape cultivar. J. Agric. Sci. Mansoura Univ., 32(11): 9347-9375.

Husia, C.L.; Luh, B.S. and Chichester C.D. (1965). Anthocyanin in free stone peach. J. Food Science, 30: 5-12.

Ministry of Agriculture statistics, (2014). Agriculture Directorates of Governorates. Publisher: Economic Affairs Sector.

Montero, F.J.; de Juan, J.A.; Cuesta, A. and Brasa, A. (2000) Nondestructive Methods to Estimate Leaf Area in Vitis vinifera L. HORTSCIENCE 35(4):696-698..

Ollat, N.; Tandonnet, J.P.; Bordenave, L.; Decroocq, L.; Geny, J.P.; Gaudillere, R.; Barrieu, F. and Hamdi, S. (2003). La vigueur conferee par Ie portegreffe: hypotheses et--pistes de recherches. Bull de rorv 76(869-870), 581-595.

Ozden, M.; Vardin, H.; Simsek, M. and Karaaslan, M. (2010). Effects of rootstocks and irrigation levels on grape quality of Vitis vinifera L. cv. Shiraz. African Journal of Biotechnology, Vol. 9(25), pp. 38013807.

Rizk-Alla, M. S., Sabry, G. H., and EL-WAHAB, M. A. (2011). Influence of some rootstocks on the performance of Red Globe grape cultivar. Journal of American Science, 7(4), 71-81.

Snedecor, G. and Cochron, W. G. (1980): Statistical Methods. Oxford and J. B. H. Publishing Com. $7^{\text {th }}$ edition.

Schmid, J.; Sopp, E.; Ruhl, E.H. and Hajdu, E. (1998). Breeding rootstock varieties with complete Phylloxera resistance. Acta Hort. 473:131-135.

Sule, S. (1999). The influence of rootstock resistance to crown gall (Agrobacterium spp.) on the susceptibility of scions in grapevine. Proceedings of New Aspects of Resistance Research on Cultivated Plants: Bacterial Diseases. 5:32-34.

Tourky, M.N.; El-Shahat, S.S. and Rizk, M.H. (1995). Effect of Dormex on fruit set, quality and storage life of Thompson Seedless grapes (Banati grapes). J. Agric. Sci. Mansoura Univ., 20(12): 5139-5151.

Turker, S. and Ak, B.E. (2010). Effect of different rootstocks on physical traits of Siirt and Ohadi Pistachio cultivars. Options Mediterranean's, 94: 245-250.

Walker, R.B.; Blackmore, D.H.; Clingeleffer, R.P. and Ray, C.L. (2002). Rootstock effects on salt tolerance of irrigated field-grown grapevines (Vitis vinifera L. cv. Sultana). I. Yield and vigor inter relationships. Austral. J. Grape and Wine Res. 8:314

Zhiyuan, Y. (2003). Study on the rootstocks for Fujiminori grape variety, South China, 32(2): 57-58. 


\section{تأثير الاصول على النمو والمحصول وجودة الثمار فى عنب رد جلوب}

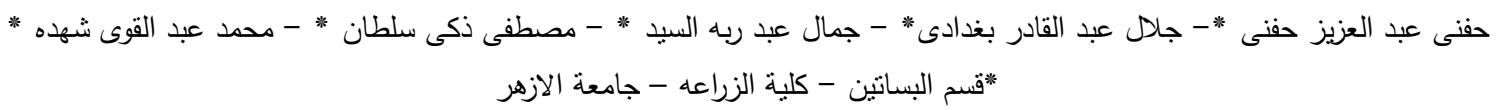

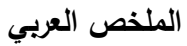

اجريت هذه الدراسه خلال عامى 2013 ، 2014 على كرمات العنب عمر 6 سنوات مزروعه بأرض رمليه فى مزرعه خاصه في وادى الملاك

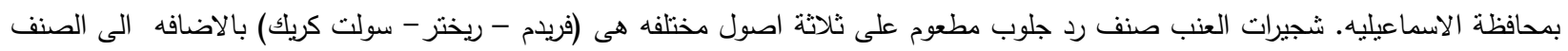

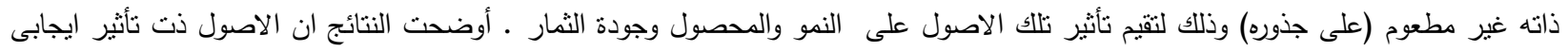

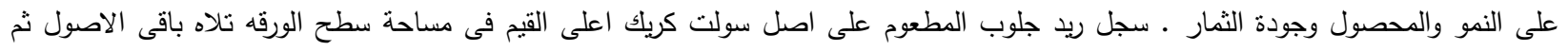

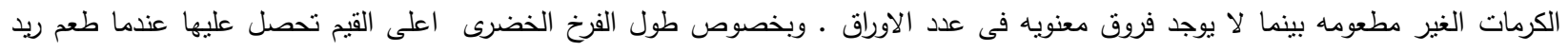

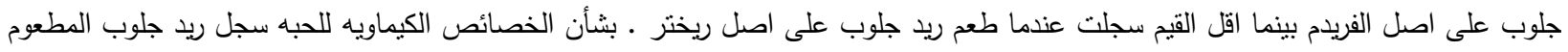

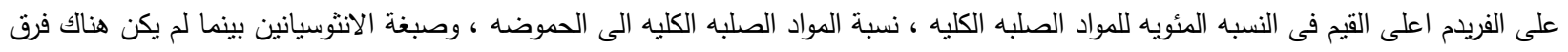

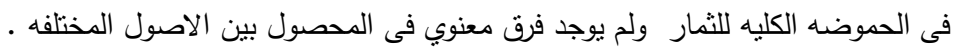

